\title{
A DESCONSTRUÇÃO DA LEGALIDADE NO TRIBUNAL DE NUREMBERG: UMA ABERTURA PARA O KAIRÓS DO PERDÃO
}

\author{
“A sentença, objeto de conservação na sociedade." \\ (Friedrich Nietzsche)
}

Igor Pereira ${ }^{1}$

\begin{abstract}
RESUMO
O presente artigo examina a questão da justiça no Tribunal de Nuremberg, problematizando o seu processo, para desvelar a ausência de uma lógica jurídica evidentemente contrária ao nazismo. Assim, fez-se um estudo da importância do princípio da legalidade no Direito Penal, definindo a sua imprescindibilidade para a atribuição de responsabilidade penal na ordem internacional. A partir dessa perspectiva, buscou-se verificar a possibilidade de haver justiça em tribunais de exceção, principalmente em momentos históricos em que a dispensa da exceção do julgamento culminaria na regra da execução sumária.
\end{abstract}

PALAVRAS-CHAVE: Direito Penal Internacional; Tribunal de Nuremberg; Desconstrução; Jacques Derrida

\begin{abstract}
This article examines the issue of justice at Nuremberg Trial, questioning its process to reveal an absence of a legal logic evidently contrary to nazism. Thus, it was made a study of the importance of the principle of legality in criminal law, defining its indispensability for the attribution of criminal responsibility in the international order. From this perspective, we sought to verify the possibility of justice in the courts of exception, especially in historical moments in which the waiver exception of the trial would culminate in the rule of summary execution.
\end{abstract}

KEYWORDS: International Criminal Law; Nuremberg Trial; Deconstruction; Jacques Derrida

\section{Noções introdutórias}

O Tribunal de Nuremberg foi paradigmático na ordem internacional, por ser a resposta "pretensamente" jurídica ao nazismo. Os Aliados, que no pós-guerra proferiam as palavras do mundo ocidental, imbuídos pelas emoções tão díspares dos combates recentes e pelo desejo de resgate do humano da desumanidade dos campos de concentração, decidiram processar e julgar a cúpula viva do nacional-socialismo, de acordo com as regras da tradição penal democrática.

Só que essa tradição penal democrática tem em seu núcleo o mandamento nullum crimen nulla poena sine lege. Para processar e julgar os "criminosos de guerra" era necessário

\footnotetext{
${ }^{1}$ Mestrando em Direito Penal pela Universidade do Estado do Rio de Janeiro (UERJ). Especialista em Direito Público e Privado pela UNESA. Pós-graduando em Análise Criminal pela Universidade Católica de Brasília (UCB). Graduado em Direito pela Pontifícia Universidade Católica do Rio de Janeiro (PUC-Rio) igorcriminalista@gmail.com.
} 
enfrentar e ultrapassar o princípio da legalidade, justificando ainda assim o direito. A inexistência de prévio tratado ou convenção, estabelecendo tipos penais internacionais que dessem conta dos fatos odiosos praticados pelos alemães nazistas, colocava em xeque a justiça do julgamento. Afinal, como atribuir responsabilidade penal aos autores dos horrores da segunda guerra, se os fatos não eram definidos como crimes na ordem internacional?

Este escrito buscará problematizar essa "questão" do Tribunal de Nuremberg. Tal evento histórico suscitou múltiplos questionamentos jurídicos, políticos e filosóficos, entretanto há uma pergunta que se separa de todas as outras, tendo destaques que se refletem no julgamento e para além dele. Ela nos põe a refletir acerca da moralidade de nossa própria resposta às lutas prévias e nos coloca desconfiados de como agir em nossas lutas futuras. Tem o condão de infligir feridas à vitória da guerra, mesclando a boa nova do fim do nazismo com a letalidade da nossa resposta. Mais ainda, ela é capaz de confundir o "nós" com o "eles", fermentando um pouco "deles" em "nós". Possui aptidão para revelar alguma inautenticidade naquela atividade judicante, pois a honestidade de nossos preceitos e de nossos agires dependem da aceitação de certo mea-culpa, mesmo diante da atividade de julgar o que consideramos ser e ter do pior. Assim, evita-se desconsiderar que o horror que julgamos haver no outro faz parte do nosso humano. Desvia-se da tentação de "monstrualizar" a destruição, pois ela é uma herança nossa. E é como herança nossa, do humano, para o humano e apesar do humano, que toda destruição deve ser percebida, para que não nos autorize a destruir o outro à desculpa e à reboque. Ela, para ser "a questão", precisa abranger o que talvez se tenha de mais utópico no direito: a pretensão de justiça.

Quer-se com ela levar justiça ao Tribunal por meio do seu próprio questionamento, desconstruindo o processo para tê-lo como minimamente justo ou pelo menos aceitável. Se não há mais como desconstruir Nuremberg na nervura de suas transformações, então que se faça a posteriori para servir de subsídio para os futuros julgamentos penais internacionais. Aqui está a pergunta que nos coloca em transe ao se pensar na problemática do julgamento "oficial” do nazismo: é possível haver justiça em tribunais de exceção?

Para pensar e jogar essa questão, sem a pretensão de derradeiramente respondê-la, optei pelo pensamento da desconstrução, sob o marco teórico do filósofo franco-argelino Jacques Derrida. Sua abordagem inédita, do direito e da justiça, pode nos ajudar a sair do lugar (in)comum em que a Justiça Criminal se encontra. Aposto no drible dos enfatismos do pensamento jurídico-penal e criminológico, para verificar se há aberturas para além das ideologias. O enfatismo está vis-à-vis com o perigo de se deixar de ouvir novas vozes. E parece ser esse o ponto que se deseja evitar após a Segunda Guerra Mundial: o de se fechar ao 
outro. É por meio das constantes aberturas a um estranho singular, que se revelam as trilhas que nos levam cada vez mais longe das ideologias de extermínio.

Antes, entretanto, faz-se mister demonstrar a importância da legalidade para o Direito Penal. Como que esse princípio é tão crucial para a justificação ou não da violência do Direito. Como que a doutrina jurídico-penal, dando aqui um enfoque maior na brasileira, toma consciência desse princípio. Assim, poder-se-á demonstrar como se queda impossível o cálculo do Direito sem a lei prévia, escrita, estrita e certa. Mas será que a justiça inexiste sem o direito?

\section{A crucialidade da legalidade para o Direito Penal}

O princípio da legalidade, da forma como o conhecemos, tem suas origens nas Constituições dos Estados de Maryland e de Virgínia (1776), na Constituição Americana (1787) e na Declaração Universal dos Direitos do Homem e do Cidadão (1789), da Revolução Francesa, quando foi formulado em termos mais precisos. O Código Penal da Bavária (1813) foi a primeira legislação penal a adotar o princípio $^{2}$. Claus Roxin, todavia, chama atenção para a presença do princípio no Código Penal austríaco de José II, de 1787, porém o governo à época era absolutista, sendo assim muitos autores consideraram que seu objetivo não era proteger o cidadão, mas sim eliminar o livre arbítrio judicial ${ }^{3}$. Segundo Nilo Batista, a Magna Carta da Inglaterra, de 1215, não contém o princípio da legalidade no seu sentido moderno, pois há também na declaração a possibilidade da invocação dos costumes ${ }^{4}$. No entanto, Anibal Bruno ${ }^{5}$ entende que a referida Magna Carta é um dos documentos originários do princípio da legalidade. Os pensadores iluministas, tais como Montesquieu, Rousseau e Beccaria, foram os principais responsáveis pela sua elaboração intelectual.

Esse célebre princípio é de suma importância para o Direito Penal, pois delimita o direito de punir (ius puniendi) do Estado, garantindo a liberdade do ser humano e os valores democráticos, tendo sido considerado a verdadeira pedra angular do Estado de Direito ${ }^{6}$. A

\footnotetext{
${ }^{2}$ SANTOS, Juarez Cirino dos. Direito Penal - Parte Geral. Florianópolis: Conceito Editorial, $4^{\mathrm{a}}$ ed., 2010 , p. 20.

${ }^{3}$ ROXIN, Claus. Derecho Penal - Parte General, t. 1. Madrid: Civitas, 2a ed., 2008, p. 142.

${ }^{4}$ BATISTA, Nilo. Introdução Crítica ao Direito Penal Brasileiro. Rio de Janeiro: Revan, 11 a ed., 2007, p. 66.

${ }^{5}$ BRUNO, Anibal. Direito Penal - Parte Geral. Rio de Janeiro: Forense, $3^{\text {a }}$ ed., 1967, p. 193-194.

${ }^{6}$ PRADO, Luiz Regis. Curso de direito penal brasileiro, parte geral: arts. $1^{\circ}$ a 120 , São Paulo: Revista dos Tribunais, $8^{\mathrm{a}}$ ed,.2008, p. 130.
} 
pena é uma sanção extremamente rigorosa, devendo apenas ser aplicada como consequência da prática de crimes. E só existirá crime se houver uma lei penal prevendo taxativamente que uma determinada conduta é criminosa. Não basta a existência do crime, para que alguém sofra as consequências da responsabilidade criminal, porque é preciso ainda que a lei preveja uma sanção penal. Não há crime sem pena (Kein Verbrechen ohne Strafe). Esse é o raciocínio extraído do brocardo jurídico nullum crimen, nulla poena sine lege, cuja formulação latina foi cunhada por Feuerbach ${ }^{7}$, estando previsto, no Brasil, nos artigos $5^{\circ}$, XXXIX, da Constituição, e $1^{\circ}$, do Código Penal ${ }^{8}$.

Nelson Hungria destacou ser a norma penal a fonte única do Direito Penal. Nas palavras do mestre: "Não há direito penal vagando fora da lei escrita" demonstra a enorme importância do princípio da legalidade para a definição do próprio Direito Penal. Sendo assim, leis penais não podem ser supridas ou complementadas pela analogia, pelos costumes e pelos princípios gerais do direito, caso se dirijam contra os cidadãos. A liberdade é um direito fundamental, que tem o princípio da legalidade como um dos seus protetores. Nas palavras de Claus Roxin:

[...] um Estado de Direito deve proteger o indivíduo não somente por meio do Direito Penal, mas também do Direito Penal. Quer-se dizer que o ordenamento jurídico não deve dispor somente de métodos e meios adequados para a prevenção do delito, mas também precisa impor limites ao emprego do poder punitivo, para que o cidadão não fique desprotegido e a mercê de uma intervenção arbitrária ou excessiva do 'Estado' Leviatã ${ }^{10}$

O jurista alemão demonstrou nesse trecho a relação aporética do Direito Penal com o Estado de Direito. As violências inscritas neles atuam a favor e contra o indivíduo. Teoricamente elas previnem e reprimem os delitos, mas também os produzem. Por isso são necessários mecanismos bloqueadores do exercício abusivo do poder punitivo, para atuar como instâncias reguladoras da dinâmica interna da violência do Estado. Há uma constante tensão entre a violência legítima e a ilegítima no interior do próprio Direito. Um sistema criminal que se quer minimamente racional precisa viver em incessante batalha contra os

\footnotetext{
${ }^{7}$ HUNGRIA, Nelson. Comentários ao Código Penal, v. 1, t.1. Rio de Janeiro: Forense, 4 Ed, 1958, p. 37-38. Não há em Feuerbach a fórmula completa do enunciado latino, que é famoso entre nós, mas sim a articulação das fórmulas, tais como "nulla poena sine lege" e "nullum crimen sine poena legali". Para mais informações, remetemos o leitor para a obra de BATISTA, Nilo. Introdução Crítica ao Direito Penal Brasileiro. p.66.

${ }^{8}$ Art. $5^{\circ}$, XXXIX, da CRFB/88: "não há crime sem lei anterior que o defina, nem pena sem prévia cominação legal". Art. $1^{\circ}$, do Código Penal: "Não há crime sem lei anterior que o defina. Não há pena sem prévia cominação legal".

${ }^{9}$ HUNGRIA, Nelson. Op. Cit., p. 13.

${ }^{10}$ ROXIN, Claus. Derecho Penal-Parte General, t. 1, p. 137, grifos do autor: “[...] un Estado de Derecho debe proteger al individuo no sólo mediante el Derecho penal, sino también del Derecho penal. Es decir, que el ordenamiento jurídico no solo há de disponder de métodos y médios adecuados para la prevención del delito, sino que también há de imponer limites al empleo de la potestad punitiva, para que el ciudadano no quede desprotegido y a merced de uma intervención arbitraria o excesiva del 'Estado Leviatán'..'
} 
vícios gerados pela sua própria atividade institucional. A legalidade é a gênese intermitente da violência que se quer legítima. É gênese, pois é a partir dela que se tem crime e sanção estatais. É intermitente, pois antes da legalidade já havia violência e após ela ainda subsistem intensas fricções e interrupções descontínuas de uma violência ilegítima, posto que o seu atuar passa ao largo da racionalidade do sistema. O seu agir se explica pela norma, mas não se justifica por ela. $\mathrm{O}$ agente possui uma função no sistema criminal conferida pela norma, porém ao atuar ultrapassa os limites de suas atribuições, pois é uma tendência natural do poder tentar derrubar os limites impostos a ele.

Tudo isso para dizer que as limitações ao Direito Penal são imprescindíveis para a sua própria compreensão como direito. Ele só pode se tornar um instrumento de proteção de direitos fundamentais, por meio de limites rígidos. A legalidade nos permite ter minimamente o conhecimento e o controle do poder que legitimamos no Estado. A sua importância se circunscreve em deixar o direito vir. Em deixá-lo aparecer para os indivíduos, sob a ótica da vedação, tornando um fato antes permitido em proibido.

É a partir da legalidade que o Direito pode ser calculado pelos cidadãos. Há nela a tarefa de permitir os cálculos dos delitos e das penas. Segundo Roxin, "o princípio da legalidade [...] serve para evitar uma punição arbitrária e não calculável sem lei ou embasada em uma lei imprecisa, ou retroativa" ${ }^{, 11}$. Entendo haver aferições criminais além da legalidade, pois o Direito Penal não apenas proíbe, mas também permite. E um dos seus modos principais de permissão está na ausência da norma. Naquilo que não foi escrito. Onde não há escrito penal, há liberdade. Sem legalidade só pode haver liberdade. A observação de caráter criminal que se pode empreender diante da ausência de normas penais é que, diante de fatos meramente imorais, danosos ou até limítrofes a tipos penais, só pode haver liberdade, tendo como consequência lógica a vedação da incidência do sistema criminal. O Direito Penal liberta, quando se cala. É nesse sentido que Roxin reafirma a antiga assertiva de Franz v. Liszt, denominando o Código Penal como "a carta magna do delinquente”. Diz Roxin:

[...] o Código Penal põe a salvo o cidadão (tanto o honrado como o desonrado) de todo castigo por uma conduta que não haja sido claramente declarada punível antes do fato. Que com ele em alguma ocasião pode ficar impune uma conduta especialmente refinada, socialmente nociva e merecedora de pena, esse é o preço que há de pagar o legislador pela falta de arbitrariedade e pela segurança jurídica. ${ }^{2}$

\footnotetext{
${ }^{11}$ ROXIN, Claus. Derecho Penal-Parte General, t. 1, p. 137.

${ }^{12}$ Ibid., p. 138, grifos do autor: "[...] el Código Penal pone a cubierto al ciudadano (tanto al honrado como al no honrado) de todo castigo por una conducta que no haya sido claramente declarada punible antes del hecho. Que con ello en alguna ocasión pueda quedar impune una conducta especialmente refinada, socialmente nociva y por ello merecedora de pena, es el precio que há de pagar el legislador por la falta de arbitrariedad y la seguridad jurídica [...]."
} 
A extrema mitigação do princípio da legalidade foi levada a cabo pelo nazismo, para atingir com mais facilidade os seus objetivos autoritários e eliminatórios. Em 1935, o legislador nacional-socialista modificou o §2, do Código Penal Alemão, inserindo a idéia de que era lícito castigar, "segundo a idéia básica de uma lei penal e segundo o são sentimento do povo"13. A partir daí o Direito Penal abriu escancaradamente as portas para a política criminal nazista, nulificando a importância da lei ao colocá-la em conjunto com o conceito de "são sentimento do povo", que nada mais foi do que uma cláusula aberta para o morticínio. Se o princípio da legalidade nos permite trabalhar com a idéia de que sem legalidade só pode haver liberdade, a sua diluição na abstração do sentimento do povo nos leva à intelecção de que, na Alemanha Nazista, sem legalidade só há liberdade, caso o indivíduo estivesse em conformidade com o desejo do partido nacional-socialista. Hungria identificou bem o mote das ideologias autoritárias: "a necessidade não tem lei" absurdo do nazismo é um exemplo contundente da importância da legalidade para a liberdade de cada ser humano. Tanto que após a Segunda Guerra Mundial, o §2, do Código Penal Alemão, foi declarado inaplicável e derrogado expressamente pelos aliados, tendo sido substituído por uma versão nova do princípio da legalidade ${ }^{15}$, o que nos remete a ligação intrínseca entre o liberalismo e a legalidade.

Roxin identificou quatro fundamentos para o princípio da legalidade ${ }^{16}$. O primeiro deles é a necessidade da vinculação do Poder Executivo e do Poder Judiciário às leis abstratas, sendo esse o postulado central do liberalismo político. Assim, os poderes do Estado estão limitados a atuar conforme o que está prescrito na lei, garantindo aos indivíduos a existência de freios à atividade persecutória e judicativa estatal.

O segundo fundamento advém do princípio da separação dos poderes, concedendo aos indivíduos a garantia de que só haverá delitos e penas, segundo a vontade do Parlamento, o qual é a instância que representa o povo mais diretamente. Conforme explana Roxin:

Mediante a divisão de poderes, que se expressa no princípio da legalidade, libera-se o juiz da função de criação do Direito, reduzindo-o à função de aplicar o Direito, enquanto que ao executivo se exclui totalmente a possibilidade de cooperar na punição e desse modo se impede qualquer abuso de poder do mesmo neste campo. ${ }^{17}$

\footnotetext{
${ }^{13}$ ROXIN, Claus. Derecho Penal-Parte General, t. 1, p. 143.

${ }^{14}$ HUNGRIA, Nelson. Comentários ao Código Penal, v. 1, t.1, p. 30.

${ }^{15}$ ROXIN, Claus. Op. Cit., p. 143.

${ }^{16}$ Ibid., p. 144-147.

${ }^{17}$ ROXIN, Claus. Derecho Penal - Parte General, t. 1, p. 145: "Mediante la división de poderes, que se expresa en el principio de legalidad, se libera al juez de la función de creación del Derecho y se le reduce a la función de aplicar el Derecho, mientras que al ejecutivo se le excluye totalmente de la posibilidad de cooperar en la punición y de ese modo se impide cualquier abuso de poder del mismo en este campo."
} 
Já o terceiro fundamento do princípio da legalidade está na teoria da coação psicológica, conforme elaborada por Feuerbach. Roxin lembra que essa tese é considerada ultrapassada por boa parte da doutrina contemporânea, mas realça que essa fundamentação poderá ser mais atual do que nunca, caso complementada com a idéia da prevenção geral positiva $^{18}$. A consecução da prevenção geral só será possível, se for dada a cada indivíduo a possibilidade de saber previamente que um determinado fato foi definido como crime, sendo a sua prática então vedada pelo Direito. Caso contrário será impossível exigir de qualquer pessoa que haja em conformidade com uma norma inexistente. Não há intimidação sem a ameaça da pena. Se não há fato punível e sanção estabelecida, então não há como demover alguém da idéia de cometer um crime, pela coação psicológica engendrada pelo Direito Penal, ou ainda fortalecer a consciência de cada um em agir conforme a norma, posto que não há lei em que se espelhar. Diz Hungria: "Se a norma penal é uma norma de conduta, rematado despropósito será exigir-se que os indivíduos se ajustem a uma norma penal... inexistente.”19

De acordo com Roxin, o princípio da culpabilidade é o quarto fundamento do princípio da legalidade, pois só se poderá falar que uma determinada conduta era culpável, se o autor sabia ou poderia ao menos verificar que ela estava proibida ${ }^{20}$. Não há como considerar um ser humano culpável por qualquer fato, caso não lhe seja dada a possibilidade de conhecer o teor da proibição. Sua responsabilidade só se constituirá em culpa, se ele violar as determinações legais. Se ele agir em contrariedade com o seu dever-ser. Segundo a lição de Jorge de Figueiredo Dias, a culpa é "a própria autoria ou participação do existir (e do serlivre) em uma contradição com as exigências do dever-ser que lhe são dirigidas logo a partir do seu característico modo-de-ser (do ser-livre)."21

Além de proteger o indivíduo de sofrer a incidência do poder de punir do estado sem previsão legal, o princípio da legalidade também o protege da mudança na interpretação judicial da lei penal e da própria execução da pena. Sendo assim, é proibida a retroatividade de critérios mais severos de interpretação da lei penal, bem como é vedado à administração pública a aplicação de falta ou sanção disciplinar sem expressa previsão legal ou regulamentar, de acordo com o determinado pelo artigo 45, da Lei de Execução Penal

\footnotetext{
${ }^{18}$ Ibid., p. 146.

${ }^{19}$ HUNGRIA, Nelson. Comentários ao Código Penal, v. 1, t.1, p. 25.

${ }^{20}$ ROXIN, Claus. Op. Cit., p. 146.

${ }^{21}$ DIAS, Jorge de Figueiredo. Liberdade, Culpa, Direito Penal. Coimbra: Coimbra Editora, $3^{\text {a }}$ ed, 1995, p. 152, grifos do autor.
} 
Brasileira. Diz Nilo Batista: "A abrangência do princípio inclui a pena cominada pelo legislador, a pena aplicada pelo juiz e a pena executada pela administração",22 .

O princípio da legalidade possui quatro funções ${ }^{23}$ :

a) Nullum crimen nulla poena sine lege praevia - A primeira função do princípio da legalidade é vedar a retroatividade da lei penal mais gravosa, que deve ser anterior ao fato praticado pelo agente. São proibidas as leis ex post facto. Está aí inscrito o princípio da irretroatividade da lei penal mais gravosa (lex gravior).A lei penal retroagirá para beneficiar o Réu, a qualquer tempo, salvo nos casos de leis excepcionais ou temporárias, na forma do artigo $3^{\circ}$, do Código Penal. Juarez Cirino dos Santos, todavia, defende que a lei penal retroagirá mesmo nos casos de leis penais temporárias ou excepcionais, pois o artigo $3^{\circ}$, do Código Penal, não foi recepcionado pela Constituição da República de 1988, tendo em vista que o artigo $5^{\circ}$, inciso XL, não dispôs sobre nenhuma exceção à irretroatividade da lei penal mais gravosa ${ }^{24}$.

b) Nullum crimen nulla poena sine lege scripta - É proibida a criação de crimes e penas pelo costume, em razão do princípio da legalidade. Só que o costume não foi completamente abolido do Direito Penal. Ele ainda possui uma função integrativa para a cognição de elementos do tipo penal, como, por exemplo, a definição do que é o "ato obsceno" (art. 233, do CP) ou qual o significado da violação do dever objetivo de cuidado nos crimes culposos, quando a atividade que acarretou o acidente não está exaustivamente regulamentada ${ }^{25}$. Entretanto em hipótese alguma poderá haver o emprego de normas consuetudinárias para criar delitos e penas. A lei penal deve ser escrita, observando o processo legislativo previsto na Constituição. No Brasil, compete privativamente a União legislar sobre Direito Penal (art. 22, inciso I, da CRFB/88), sendo o Congresso Nacional a sua fonte de produção (art. 48, da CRFB/88). É preciso haver lei em sentido formal para a cominação de crimes e penas, por força da exigência da reserva absoluta de lei. Nesse sentido, há divergência doutrinária sobre a constitucionalidade das leis penais em branco heterogêneas ou próprias, que possuem pena determinada, mas preceito penal indeterminado, dependendo de atos normativos inferiores para definir o exato alcance do tipo penal, como, por exemplo, o tipo de omissão de

\footnotetext{
${ }^{22}$ BATISTA, Nilo. Introdução Crítica ao Direito Penal Brasileiro, p. 68, grifos do autor.

${ }^{23}$ Ibid., p. 68.

${ }^{24}$ SANTOS, Juarez Cirino dos. Direito Penal - Parte Geral, p. 52.

${ }^{25}$ BATISTA, Nilo. Op. Cit., p. 70-71.
} 
notificação de doença, previsto no artigo 269, do Código Penal. No Brasil, a doutrina majoritária entende que as leis penais heterogêneas ou próprias respeitam o princípio da legalidade, quando o núcleo essencial da conduta está previsto na lei em sentido formal ${ }^{26}$, restando aos atos normativos inferiores apenas especificar o alcance dos elementos já contidos no próprio tipo legal. Juarez Cirino dos Santos diverge desse posicionamento, entendendo que as leis penais em branco heterogêneas ou próprias transferem a competência legislativa ao Poder Executivo ou a atos inferiores do próprio poder legislativo, sendo assim desrespeitada a reserva absoluta de $1 \mathrm{ei}^{27}$.

c) Nullum crimen nulla poena sine lege stricta - A terceira função do princípio da legalidade é vedar a utilização da analogia (in malam partem) para criar crimes, agravar ou fundamentar penas. A analogia é um procedimento lógico, que consiste na aplicação da norma jurídica de um caso previsto a um caso não previsto, em razão da semelhança entre ambos. Ela supre uma lacuna na lei. Está prevista no artigo $4^{\circ}$, da Lei de Introdução do Código Civil, sendo proibida no Direito Penal para agravar a situação do réu, todavia esse procedimento lógico é permitido, se beneficiar a defesa. A analogia in bonam partem é aceita pela doutrina amplamente majoritária ${ }^{28}$, sob o argumento que o princípio da legalidade existe para salvaguardar o ser humano em face do Estado, e não para agravar a sua situação, pondo-se como um obstáculo à liberdade. Nelson Hungria isoladamente defende a impossibilidade do emprego da analogia in bonam partem, pois a lei penal seria um sistema fechado, que enfrentaria um grave perigo de subversão, caso se permita ao magistrado a criação arbitrária de causas de excepcional licitude, de impunibilidade ou não-culpabilidade penal ${ }^{29}$. Por fim, a analogia não se confunde com a interpretação analógica ou ainda com a interpretação extensiva. A primeira decorre de determinação expressa da própria lei penal, já a segunda tem como fim interpretar o sentido da norma, ampliando a sua abrangência. Ambas são permitidas pelo direito penal, em determinadas situações.

d) Nullum crimen nulla poena sine lege certa - O princípio da legalidade proíbe incriminações vagas e indeterminadas. A lei penal deve ser certa. É necessário que

\footnotetext{
${ }^{26}$ GRECO, Rogério. Curso de Direito Penal-Parte Geral. Rio de Janeiro: Impetus, 12a ed, 2010, p. 24.

${ }^{27}$ SANTOS, Juarez Cirino dos. Direito Penal - Parte Geral, p. 50.

${ }^{28}$ Por todos, BITENCOURT, Cezar Roberto. Tratado de Direito Penal - Parte Geral. São Paulo: Saraiva, $14^{\mathrm{a}}$ ed., 2009, p. 166.

${ }^{29}$ HUNGRIA, Nelson. Comentários ao Código Penal, v. 1, t. 1. p. 91-93.
} 
o tipo contenha elementos claros, que definam precisamente o que se está proibindo. Evita-se assim ambiguidades, incertezas, indeterminações e elementos genéricos, que deixariam em aberto o conteúdo da lei, para ser preenchido pelo intérprete ao sabor das intempéries dos sentimentos humanos e da política criminal vigente. A doutrina costuma expor a Lei de Segurança Nacional (Lei 7110/83), como a grande violadora da referida função do princípio da legalidade no Brasil ${ }^{30}$. A lei penal deve ser taxativa. É nessa função que se dá ensejo ao princípio da taxatividade, como uma especificação do próprio princípio da legalidade, revelando a exigência de precisão e clareza da lei penal, para que ela seja de fácil compreensão, proporcionando segurança aos seus destinatários, cumprindo assim a sua missão constitucional de servir de baluarte do Estado Democrático de Direito. O criminalista Nilo Batista enfatiza que há "um direito subjetivo público de conhecer o crime, correlacionando-o a um dever do Congresso Nacional de legislar em matéria criminal sem contornos semânticos difusos"31.

A intelectual Judith Shklar realça a intrínseca ligação da Justiça Criminal com o princípio da legalidade, como se ambos fossem um amálgama, que limitaria os crimes e as punições, protegendo o indivíduo da ação governamental. Em suas palavras: "O princípio da legalidade [...] é a justiça criminal." ${ }^{32} \mathrm{O}$ verbo ser é empregado enfaticamente, para que fique claro como na perspectiva do legalismo a justiça se condensa na lei. Sem legalidade a justiça criminal não existe. Torna-se um processo diferente com signos parecidos, quebrando o sistema de proteção da liberdade.

Nessa linha de raciocínio, há toda uma teia simbólica que nos faz crer em uma Justiça Criminal, mas na verdade estamos diante de uma decisão puramente política. Esse modo de julgar com signos tão limítrofes ao que se entende por justiça criminal é o que caracteriza os julgamentos políticos. Há nesses julgamentos a aparência de direito penal e de direito processual penal, entretanto a sua condição sine qua non não existe, porque há crimes definidos sem lei e punições sem crime. Neles o princípio da legalidade está ausente, sem que seja suprida a sua demanda específica da existência prévia de uma lei identificadora do direito, cuja força normativa tornará as condutas consideradas inadequadas em criminosas,

\footnotetext{
${ }^{30}$ GRECO, Rogério. Curso de Direito Penal - Parte Geral, p. 93; BATISTA, Nilo. Introdução Crítica ao Direito Penal Brasileiro, p. 78-79.

${ }^{31}$ BATISTA, Nilo. Introdução Crítica ao Direito Penal Brasileiro, p. 80.

${ }^{32}$ SHKLAR, Judith N. Legalism - Law, Morals and Political Trials. London: Harvard University Press, 1986, p. 152, grifo da autora: "The principle of legaity - that there shall be no crime without law, and no punishment without a crime - is criminal justice. In limiting both crime and punishment by a system of rules, this policy aims at protecting individuals against arbitrary governmental action."
} 
posto que esse efeito é produzido unicamente por ela ${ }^{33}$. Judith Shklar lembra ainda que, na ideologia do legalismo, defende-se o apartamento do direito e da política, para prevenir a arbitrariedade. "A política é considerada não somente como algo apartado da lei, mas inferior a lei." ${ }^{, 34}$. Em relação ao Tribunal de Nuremberg, Nelson Hungria identificou com clareza os problemas advindos desse julgamento político:

O Tribunal de Nuremberg há de ficar como uma nódoa da civilização contemporânea: fez tabula rasa do nullum crimen nulla poena sine lege (com um improvisado Plano de Julgamento, de efeito retroativo, incriminou fatos pretéritos e impôs aos seus autores o "enforcamento" e penas puramente arbitrárias); desatendeu ao princípio da "territorialidade da lei penal"; estabeleceu a responsabilidade penal de indivíduos participantes de tais ou quais associações, ainda que alheios aos fatos a elas imputados; funcionou em nome dos vencedores, que haviam cometido os mesmíssimos fatos atribuídos aos réus; suas sentenças eram inapeláveis, ainda quando decretavam a pena de morte. ${ }^{35}$

Essa breve análise do princípio da legalidade foi necessária para realçar a sua extrema importância para o Direito Penal. Só por meio do realce do caráter nuclear desse princípio, que será possível trabalhar com a existência do seu contraponto para a justiça. Mostrou-se nestas últimas páginas como a legalidade é importante para fundamentar, funcionalizar e compreender o Direito Penal tal como ele é. Abre-se, a partir daí, o desafio de pensar as possibilidades da justiça sem ela. Será legítimo instituir um Direito futuro para julgar fatos pretéritos? Ou esse julgamento não seria nada mais do que uma vingança institucionalizada?

Nessa trilha, passo a analisar a questão da justiça no Tribunal de Nuremberg, que foi de modo contumaz questionada, em razão da ausência do princípio da legalidade. Busco esclarecer em que medida se pode falar em justiça nos tribunais de exceção e, tomando por parâmetro Nuremberg, tentarei desconstruir o seu processo para tentar captar, mesmo de modo fugaz, qual foi o princípio do direito que mais sofreu com a sua existência.

\section{A legalidade no Tribunal de Nuremberg}

No outono de 1941, tornou-se pública a execução continuada de reféns inocentes na França, levada a cabo pelos alemães nazistas. O presidente norte-americano Franklin Delano Roosevelt contestou veementemente essa prática, anunciando que os responsáveis iriam

\footnotetext{
${ }^{33}$ Ibid., p. 152: "O que o princípio da legalidade demanda é a lei e ainda que o fato tenha se tornado criminoso pela lei. Em causas políticas, um ou outro, ou ambos estão faltando [...].

${ }^{34}$ Ibid., p. 111.

${ }^{35}$ HUNGRIA, Nelson. Comentários ao Código Penal, v. 1, t. 1. p. 31, grifos do autor.
} 
responder futuramente pelos seus atos. Sua declaração foi depois fortificada pelo primeiroministro do Reino Unido Winston Churchill e pelo governo soviético, cuja população sofreu intensas baixas pela força do punho alemão, que protestou diplomaticamente pelos seus prisioneiros de guerra e civis exterminados, atribuindo a responsabilidade ao governo de Hitler. Pelas palavras do General de Gaulle, líder das Forças Francesas Livres, a França também manifestou a sua intenção de punir os nazistas responsáveis pelos excessos nas batalhas e pelas guerras de agressão. Entretanto, o modo como a responsabilização dos nazistas iria ocorrer ainda não estava certa, na mente dos aliados. Churchill inicialmente "havia pensado em caçar os nazistas e executá-los"36.

A partir daí, seguiram-se diversas discussões e declarações entre as potências aliadas, com o intuito de responsabilizar os alemães pelas atrocidades da Guerra, como a "Declaração de Moscou", assinada por Stalin, Roosevelt e Churchill, que delineou o estilo de julgamento a ser empreendido, estabelecendo inclusive a divisão dos criminosos de guerra em dois grupos: "grandes" e "pequenos". Em 1943, iniciaram-se os trabalhos da "Comissão das Nações Unidas para Crimes de Guerra” (CNUCG), cuja missão era descobrir os responsáveis pelos crimes, concentrar e apreciar as provas. As cartas estavam lançadas para um futuro acerto de contas com as práticas de guerra alemãs. Nas assinaturas de Cretin e Bazelaire:

(...) nas conferências de Moscou e de Teerã em 1943, de Yalta e de Postdam em 1945, as três grandes potências, Estados Unidos, União das Repúblicas Socialistas Soviéticas e Grã-Bretanha, fazem um acordo para que sejam julgados e punidos os responsáveis pelos crimes de guerra. Em seguida, o tribunal militar internacional é criado pelos acordos de Londres em 8 de agosto de 1945 ocorridos entre as quatro grandes potências. Nesse meio tempo, a França juntou-se às três outras. ${ }^{37}$

A certeza mundial acerca da "Solução Final da Questão Judaica" foi decisiva para a potencialização do clamor irrefreável pela responsabilização de Hitler e seus subordinados. O professor Carlos Eduardo Adriano Japiassú, precursor nos estudos de Direito Penal Internacional no Brasil, explica que "a chamada questão judaica teve três soluções: inicialmente, a expulsão; após, a deportação para campos de concentração; e, no final, o extermínio" "38 O insigne mestre da UERJ afirma ainda ter sido a "revelação da realidade cruel da Segunda Guerra Mundial” que provocou por fim a criação do Tribunal de Nuremberg, para

\footnotetext{
${ }^{36}$ BAZELAIRE, Jean-Paul; CRETIN, Thierry. A justiça penal internacional: sua evolução, seu futuro: de Nuremberg a Haia. Barueri: Manole, 2004, p. 20.

37 BAZELAIRE, Jean-Paul; CRETIN, Thierry. A justiça penal internacional: sua evolução, seu futuro: de Nuremberg a Haia, p. 20-21.

38 JAPIASSÚ, Carlos Eduardo Adriano. O Direito Penal Internacional. Belo Horizonte: Del Rey, 2009 , p. 70. Realçando ainda o ódio dos alemães pelos judeus, explana o autor: "Em 1935, após uma grande jornada do Partido Nazista em Nuremberg, são proclamadas as leis raciais e, em 1938, ocorre a 'Kirstallnacht ou Noite dos Cristais, em que 7.500 vitrinas de lojas judaicas foram quebradas, todas as sinagogas foram incendiadas e 20 mil judeus foram levados para campos de concentração'. Este incidente deu a exata noção da capacidade de destruição e perseguição dos nazistas em relação ao povo judeu." (grifo do autor)
} 
julgar os "responsáveis pelo desencadeamento de toda a sorte de atrocidades cometidas sob a égide do nazismo"39.

A palavra holocausto, oriunda do grego antigo, significa "sacrifício pelo fogo" ". Ao exterminar judeus, ciganos, homossexuais, testemunhas de Jeová, comunistas e socialistas, as autoridades alemães julgavam fortalecer a sua raça considerada superior, limpando do mundo, e principalmente da Alemanha, as raças consideradas inferiores. Nesse sentido, sacrificar pelo fogo é purificar o seu mundo de elementos destrutivos, ignóbeis ou pelo menos inconvenientes. É provocar o desaparecimento da "indignidade do mundo", em razão da sua inferioridade. Para os nazistas a indignidade estava na face do outro. A diferença devia ser exterminada para dar vazão à supremacia de sua unicidade. Os seus aspectos culturais deveriam se expandir, em uma constante defesa de si-mesmo. E o outro era humano. O holocausto nazista buscou consolidar a "limpeza do mundo" dos humanos em diferença cultural. Por isso a resposta a esses atos pareciam ser irrefratáveis. Era preciso atribuir responsabilidade ao ser humano, quando tenta se livrar de si-mesmo. Não eram homicídios que retiravam do mundo dois ou mais homens, mas sim extermínios de aspectos cruciais do desenvolvimento e da existência da humanidade. O pleito era fazer morrer uma parte da própria humanidade. Extinguir aspectos não considerados de si-mesmo no outro. Parece ser a partir dessa constatação de supressão do outro, que se deve entender o holocausto nazista e talvez também o Tribunal que o julgou. Focar-se justamente nesse ponto pode ser uma boa estratégia para uma perspectiva desconstrutivista da legalidade em Nuremberg.

Afinal, em 1945, os alemães já tinham assassinado dois entre três judeus europeus (os números são incertos, todavia se costuma falar no extermínio de 6.000 .000 de judeus). Foram 200.000 ciganos assassinados. Em torno de outros 200.000 doentes incuráveis, idosos senis, deficientes físicos e mentais destruídos pelo "Programa Eutanásia". Entre dois e três milhões de soviéticos prisioneiros de guerra foram assassinados ou deixados à cruel espera da morte $^{41}$. Ousaria falar em uma programação letal do sentido do mundo, produzindo a morte para deixar apenas uma vida uníssona aos desejos do partido nacional-socialista. Sem falar nos sobreviventes, que vivenciaram situações subumanas nos campos de concentração. A "solução final judaica", um eufemismo para a morte, foi a medida tomada pelo nazismo para desconsiderar a humanidade e a vida. É nesse sentido que interpreto o holocausto como uma

\footnotetext{
${ }^{39}$ Ibid., p. 69.

${ }^{40}$ United States Holocaust Memorial Museum. Enciclopédia do Holocausto. Apresenta informações sobre o Holocausto. Disponível em: <http://www.ushmm.org/museum/exhibit/focus/portuguese/>. Acesso em: 28 ago. 2010.

${ }^{41}$ Dados obtidos em: United States Holocaust Memorial Museum. Enciclopédia do Holocausto. Disponível em: <http://www.ushmm.org/wlc/ptbr/article.php?ModuleId=10005143\&referer=focus>. Acesso em: 29 ago. 2010.
} 
tentativa do ser humano de exterminar aspectos não considerados de si-mesmo. O nazismo atacou parte da história cultural do homem, pertencente de certa monta também ao próprio povo alemão. O Tribunal de Nuremberg vinha como uma resposta a essa atitude. Foram julgamentos para punir essas desumanidades. Foi também uma pretensa alternativa a uma vingança internacional que seria irrefreável, tendo em vista as paixões reativas ao nazismo, principalmente as soviéticas. Diz Japiassú:

Certamente foi uma corte de vencedores que julgavam vencidos. Mas, apesar disso e apesar da opinião pública mundial ter desenvolvido imensa repulsa pelos atos praticados pelo Estado nazista, tentou-se, na medida do possível, fazer de Nuremberg um julgamento e não um exercício de vingança internacional. E parece que, com todas as dificuldades, alcançou-se relativo êxito. ${ }^{42}$

Apesar dos pesares das violências, o julgamento aconteceu e, em 8 de agosto de 1945, em Londres, foi assinado pelos Aliados (França, URSS, Grã-Bretanha e EUA) o acordo constitutivo do Tribunal Internacional Militar dos Grandes Criminosos de Guerra, ente competente para processar e julgar os atos praticados pelos nazistas e quem estivesse a eles relacionados. O julgamento aconteceria em Nuremberg. Em toda a medida, a "Noite dos Cristais" (Kristallnacht) iria se voltar contra os nazistas. A cidade, já sem muitos vidros restantes para serem quebrados, seria o local de despedida daqueles que empreenderam o ato do século XX que nos fez ter vergonha de sermos humanos.

O processo ocorreu entre 20 de novembro de 1945 e $1^{\circ}$ de outubro de 1946, tendo como presidente o juiz britânico Geoffrey Lawrence. 24 nazistas e seis organizações ${ }^{43}$ estavam envolvidas. As sentenças são proferidas em 30 de setembro e $1^{\circ}$ de outubro de 1946. Robert Ley não foi julgado, pois cometeu suicídio na prisão de Nuremberg. Gustav Krupp Von Bohlen und Halback foi beneficiado por uma "classificação sem continuidade das acusações das quais ele era objeto em função de um acidente de trânsito sofrido em 1944"44. Não obstante ter sido condenado à morte, Herman Göring suicidou-se com cianureto às vésperas de sua execução. Foram 19 condenações, sendo 12 sanções de pena de morte, e 3 absolvições $^{45}$. O NSDAP, a Gestapo e as SS são declaradas organização criminosas. Nas palavras de Bazelaire e Cretin:

\footnotetext{
${ }^{42}$ JAPIASSÚ, Carlos Eduardo Adriano. O Direito Penal Internacional, p. 76.

${ }^{43}$ BAZELAIRE, Jean-Paul; CRETIN, Thierry. A justiça penal internacional: sua evolução, seu futuro: de Nuremberg a Haia, p. 24.

${ }^{44}$ Ibid., p. 25.

${ }^{45}$ GONÇALVES, Joanisval Brito. Tribunal de Nuremberg 1945-1946: a gênese de uma nova ordem no direito internacional. Rio de Janeiro: Renovar, 2001, p. 192-193: “(...) 12 foram condenados à forca - Bormann, julgado in absentia, Frank, Frick, Goering, Jodl, Kaltenbrunner, Keitel, Ribbentrop, Rosenberg, Sauckel, SeyssInquart e Streicher -, 3 receberam prisão perpétua - Funk, Hess e Raeder -, 2 foram condenados a 20 anos de reclusão - Schirach e Speer -, Von Neurath foi sentenciado a 15 anos de prisão, Doenitz a 10 anos; 3 foram absolvidos - Fritzsche, Von Papen e Schacht."
} 
Em 16 de outubro, os condenados à morte são enforcados no ginásio da prisão de Nuremberg. Seus corpos são em seguida incinerados em um crematório de Munique e suas cinzas jogadas em um afluente do rio Isar. A partir de 18 de julho de 1947, os condenados à prisão são transferidos para a prisão dos Aliados em Berlim-Spandau reservada aos criminosos de guerra. ${ }^{46}$

A banalização da morte foi um dos motivos principais para os Aliados estarem diante do julgamento ou da vingança. Era preciso reagir de alguma forma. As emoções impeliam em direção a isso. Falar em um julgamento de acordo com os valores ocidentais poderia vir a significar uma tentativa de inserir alguns aspectos racionais relevantes, entre os desejos de vingança e de resposta às atrocidades. Era preciso inserir na história alguma decisão contra os morticínios, para que futuramente as consciências humanas vindouras não percebessem todos aqueles tremores como consequências naturais de uma guerra. Entretanto, o enfrentamento da legalidade para estabelecer um julgamento não acarretou em um resultado menos violento. Aí está a perspectiva desconstrutivista deste tópico. Desconsideramos completamente o outro em Nuremberg por nos parecer monstruoso, tal como fez o nazismo. Era preciso que o "direito" se desse na nervura dos acontecimentos, para travar um poder punitivo incontrolável. Um "direito" que após o fato viria para garantir um mínimo de dignidade, vedando a pena de morte e quiçá a prisão perpétua. Faltou um esforço hercúleo para evitar assassinar os nazistas. Assim, na trilha de Rafael Haddock-Lobo:

Conseqüentemente, para além de uma filosofia pragmática, o pensamento deve edificar sua estrutura sistêmica a partir dessa contaminação pela alteridade; deve, na assunção de sua culpa, como modelo de pensamento que por séculos esmagou, calou e tentou aniquilar as diferenças, nessa culpa, em suas mãos sujas de sangue, encontrar a razão para estendê-las a quem pede; e deve, para aquém e além da culpa, destampar seus ouvidos para que se possa ouvir a voz daqueles que chamam e abrir seus olhos para que se veja o rosto do outro. ${ }^{47}$

Não há como negar que o Tribunal de Nuremberg foi uma corte de exceção. Ele foi criado justamente em função dos atos pretéritos dos nazistas, considerados criminosos pelos Aliados, e foi extinto logo após as sentenças terem sido proferidas. O seu caráter ad hoc é evidente. Joanisval Brito Gonçalves chegou a dizer que "Nuremberg revelava-se uma Corte em moldes semelhantes aos Tribunais do III Reich, onde as regras procedimentais eram

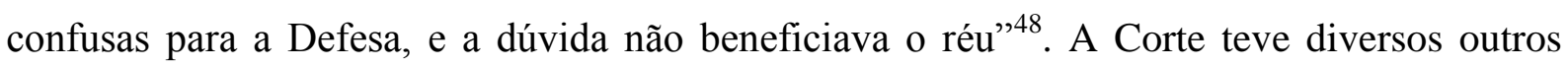
problemas, como o procedimento misto, com prevalência do modelo anglo-saxão - estranho aos nazistas -, as dúvidas que pairavam sobre a imparcialidade dos juízes, a ausência de recursos, mesmo diante da pena de morte, e a impossibilidade dos acusados levantarem

\footnotetext{
${ }^{46}$ Ibid., p. 27.

${ }^{47}$ HADDOCK-LOBO, Rafael. "As muitas faces do outro em Levinas". In: DUQUE-ESTRADA, Paulo Cesar (Org.). Desconstrução e ética - ecos de Jacques Derrida. Rio de Janeiro : Ed. Puc-Rio, 2004, p. 192.

${ }^{48}$ GONÇALVES, Joanisval Brito. Tribunal de Nuremberg 1945-1946: a gênese de uma nova ordem no direito internacional, p. 151.
} 
tópicos de política internacional ${ }^{49}$. Entretanto, este artigo se concentra apenas na tarefa de avaliar o problema da ausência do princípio da legalidade. Se houvesse alguma forma de realizar um julgamento respeitando os seus preceitos, boa parte das contendas supracitados estariam resolvidas por arrastamento. Só que respeitá-los era impossível. Na época, a única forma de respeitá-los seria deixar de julgar. Uma omissão também impossível. Esteve-se então diante de duas "impossibilidades". Fazer o Direito Penal atuar sem lei prévia, escrita, estrita e certa. Assim sendo, calcular sem cálculo. E ultrapassar o princípio da legalidade para se fazer justiça, pois respeitá-lo seria aceitar a vingança pública e coletiva. As declarações de Robert Jackson, promotor-chefe de Nuremberg, são importantes para revelar o dilema histórico:

$\mathrm{Na}$ primeira audiência do processo de Nuremberg, Robert Jackson faz uma declaração preliminar: 'O privilégio de abrir o primeiro processo na história dos crimes contra a paz do mundo é uma grande responsabilidade'. 'As quatro grandes nações vitoriosas [...] detêm o braço da vingança e submetem voluntariamente os seus inimigos prisioneiros ao julgamento da lei'. 'Os crimes pelos quais buscamos condenar e punir não pode tolerar que sejam ignorados, pois não poderíamos sobreviver se eles fossem reiterados. ${ }^{50}$

Ana Luiza Almeida Ferro afirma ter sido a falta da legalidade um dos maiores argumentos da defesa, que assim foram demarcados:

a) O castigo ex post facto é repudiado pelo Direito das nações civilizadas;

b) nenhum poder soberano atribuíra à guerra de agressão a tipificação de crime antes da prática dos atos incriminados;

c) nenhum estatuto a definira, nenhum documento internacional previra pena para a sua prática, assim como nenhum tribunal fora instituído para julgar e punir os infratores. 51

Os argumentos da acusação eram muito frágeis diante das demarcações estritas exigidas pelo princípio da legalidade. Não havia previsão de pena para o crime de guerra ilícita, então não haveria a possibilidade de aplicar qualquer sanção. Prevenir politicamente os nazistas de que seus atos não restariam impunes não é capaz de criar Direito, apenas reforça o caráter político do julgamento. Por fim, a alegação de que os atos praticados vão de encontro à consciência universal é incapaz de fraquejar a legalidade estrita, que exige lei prévia e escrita. $\mathrm{O}$ melhor argumento parece ter sido aquele que afirma o caráter costumeiro do Direito Penal Internacional, diferenciando-se do direito interno. A acusação ainda considerou o fato de que "tal princípio não se encontra na base de todas as legislações dos povos anglo-saxões, tendo sido ainda estranho ao Direito romano e repudiado pela própria legislação penal do

\footnotetext{
${ }^{49}$ Para mais informações, recomenda-se a leitura de FERRO, Ana Luiza Almeida. O Tribunal de Nuremberg: dos precedentes à confirmação de seus princípios. Belo Horizonte: Mandamentos, 2002, p. 103.

${ }^{50}$ BAZELAIRE, Jean-Paul; CRETIN, Thierry. A justiça penal internacional: sua evolução, seu futuro: de Nuremberg a Haia, p. 42.

${ }^{51}$ FERRO, Ana Luiza Almeida. Op. Cit., p. 103.
} 
nazismo alemão" ${ }^{, 52}$. Parece que esse argumento é inábil para afastar a importância dos tratados para fixar responsabilidades penais na ordem internacional, além de reforçar a ausência do princípio da legalidade, ao defender sua desimportância. Há ainda a afirmação de que, por existirem pactos internacionais prevendo a proibição de determinados atos internacionais, tal como o Pacto Briand-Kellog, o princípio nullum crimen nulla poena sine lege somente foi amenizado em Nuremberg, e não propriamente desrespeitado ${ }^{53}$. Ora, princípios penais não podem ser "amenizados" contra os seres humanos. Eles não podem ser relativizados para autorizar o direito de matar. A atividade de "amenizar" o princípio é desrespeitá-lo com sutileza. O princípio da legalidade não aceita tapas de luvas de pelica.

\section{A desconstrução da legalidade no Tribunal de Nuremberg}

Concordo, por tudo o que até agora foi dito, com os dizeres de Kelsen, ao refutar a possibilidade das decisões de Nuremberg serem consideradas um precedente judicial. O jurista austríaco, com elegante tom irônico, argumentou que, se tal julgamento for considerado um precedente - legislativo -, então se deve esperar das guerras vindouras o julgamento dos perdedores pelos Estados vencedores, pelo cometimento de crimes determinados unilateralmente e com força retroativa ${ }^{54}$. Um precedente desse tipo não deve ser reconhecido ou querido. Kelsen quis dizer que o ocorrido em Nuremberg não é um ideal a ser seguido. Entretanto, isso não significa que a criação de um Direito Penal Internacional seja indesejável. Pelo contrário, talvez esse fenômeno histórico tenha nos alertado da importância e do risco de se engendrar um sistema internacional de responsabilidade criminal individual, de acordo com os princípios penais e processuais penais historicamente consagrados. Estevese, em Nuremberg, diante de processos e sentenças políticas, cujas forças não constituíram um Direito Penal e um Direito Processual Penal. Firmou-se uma "racionalidade" aparente de Direito, para dar uma resposta de exceção aos atos praticados pelos nazistas.

\footnotetext{
${ }^{52}$ FERRO, Ana Luiza Almeida. O Tribunal de Nuremberg: dos precedentes à confirmação de seus princípios, $\mathrm{p}$. 105. Faz-se mister lembrar que o Pacto Briand-Kellog não firmou nenhuma responsabilidade criminal individual. O próprio Hans Kelsen proferiu essa assertiva em: KELSEN, Hans. Will the judgment in Nuremberg Trial constitute a precedent in International Law? The International Law Quarterly, v. 1, n. 2, p. 153-171, 1947, p. 155 .

${ }^{53}$ Ibid., p. 108.

${ }^{54}$ KELSEN, Hans. Will the judgment in Nuremberg Trial constitute a precedent in International Law? The International Law Quarterly, p. 171.
} 
Por outro lado, o fato de não se poder falar nesse caso em um Direito Penal Internacional não implica necessariamente no afastamento da justiça criminal. Quiçá seja possível uma justiça criminal sem legalidade, quando as pulsões punitivas sejam irrefreáveis, em razão da magnitude histórica dos fenômenos, a urgir alguma atribuição de responsabilidade a indivíduos que colocaram em risco o mundo da vida. Uma "justiça jurídica" com cálculo posterior não deve ser jamais preferida, entretanto nada impede a existência de casos em que seja necessário ultrapassar a legalidade para evitar violências maiores. Vamos então buscar a justiça do caso na desconstrução, pois os princípios jurídicos liberais por si só não são capazes de travar a potência de momentos históricos de exceção. Em certa medida, parece ser possível dizer que Nuremberg delineou um ponto crítico de uma ordem internacional de exceção, em que o fato político e o jurídico se misturaram. Nesse plano crítico e aporético, circunscreve-se a consagrada frase do decisionismo de Carl Schmitt: "Soberano é aquele que decide sobre o estado de exceção" "55. Ironicamente, os poderes dos Aliados na ordem jurídica internacional configuraram uma soberania fática, incumbida de decidir sobre o destino dos nazistas. As teorias do decisionismo, da exceção e da soberania, elaboradas por Schmitt, voltaram-se contra os próprios alemães, circunscrevendo uma instância de poder, que suspendeu a ordem jurídica internacional para efetivar o desastremilagre da exceção.

Entendendo essa situação como inescapável, tem-se como possível a percepção de que a ausência do olhar desconstrutivista em Nuremberg foi um dos motivos principais para a violência do seu resultado, pois não foi dada a devida atenção aos processos de transformações, no intento de radicalizá-los para buscar uma quebra à violência nazista. E desconstruir não é destruir. Desconstrói-se ao abrir novas possibilidades nos processos de transformação, renunciando a tranquilidade ao tratar do Tribunal de Nuremberg, aceitando o desafio de pensá-lo como uma aporia, onde reside a resposta à violência e a própria violência. Desconstruir é fazer e deixar que se faça justiça nos processos históricos. Para se fazer "justeza" ao tema é preciso verificar o que lá não foi percebido ou dito. A desconstrução acontece ao pensarmos que a Corte não abriu espaço para serem renunciados determinados aspectos da violência ao julgá-la. O "direito" veio a posteriori e, para que o cálculo produzido por ele fosse querido ao ultrapassar o princípio da legalidade, era necessário renunciar à morte, pois ao aplicá-la como pena o "direito" foi vingança. Em nada se diferenciou dela,

\footnotetext{
${ }^{55}$ SCHMITT, Carl. Teología política - cuatro ensayos sobre la soberanía. Buenos Aires: Struhart \& Cia, 2005, p. 23.
} 
apenas deu a todos nós as ilusões de uma razão escamoteadora do quanto nos espelhamos "neles" ao matá-los. Parafraseando Dostoievski, ao não darmos sombra de esperança aos nazistas, sabíamos que íamos falhar.

Assumimos com as execuções em Nuremberg um derramamento de sangue não previsto. Se a efusão de sangue já é um processo que deve ser evitado e, na esmagadora maioria das vezes, severamente combatido, o cruor dos nazistas resultou no desastre da glorificação do que justamente queríamos anular: a violência exacerbada, a programação do futuro com sangue e os genocídios. Derrida possui um bom trecho sobre o assunto, merecendo a citação integral:

Nem toda crueldade é sangrenta ou sanguinária, visível e exterior, decerto; pode ser, provavelmente é, essencialmente psíquica (prazer obtido em sofrer ou em fazer sofrer, ver sofrer; grausam, em alemão, não nomeia o sangue). Mas cruor designa de fato o sangue derramado, a efusão e portanto uma certa exterioridade, uma visibilidade do vermelho, sua expressão do lado de fora, essa cor que inunda todos os textos de Victor Hugo contra a pena de morte, desde o vermelho que a guilhotina faz correr, 'a velha bebedora de sangue', 'a horrível máquina escarlate', até os andaimes de madeira vermelha que sustentavam sua lâmina ('duas vigas compridas pintadas de vermelho, uma escada pintada de vermelho, um cesto pintado de vermelho, uma escada pintada de vermelho em que se parece encaixar por um dos lados uma lâmina grossa e enorme triangular... eis a civilização que chegava à Argélia sob a forma da guilhotina'). ${ }^{56}$

O choque causado pelos atos perpetrados pelos nazistas se deu justamente pela visibilidade do vermelho, todavia decidimos dar uma resposta com ainda mais derramamento de sangue, que se efetivou no suplício da execução pela forca. Método de matar humilhante, agonizante e sufocante. Essa não parece ter sido uma alternativa razoável para ultrapassar o princípio da legalidade, pois o desfecho do julgamento foi muito parecido ao de uma execução sumária.

Uma análise do discurso de abertura de Robert H. Jackson, o principal promotor norte-americano em Nuremberg, ajudará a melhor compreender o dilema. Jackson disse: “O privilégio de abrir o primeiro julgamento na história de crimes contra a paz mundial impõe uma grave responsabilidade. As injustiças que pretendemos condenar e punir foram tão calculadas, tão malignas e tão devastadoras, que a civilização não pode admitir que sejam

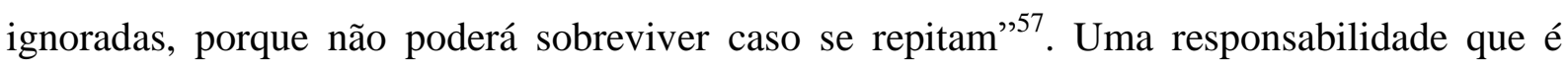
grave por ser o primeiro julgamento após atos devastadores, calculados e malignos, tendo

\footnotetext{
${ }^{56}$ DERRIDA, Jacques; ROUDINESCO; Elizabeth. De que amanhã: diálogo. Rio de Janeiro: Jorge Zahar Ed., 2004, p. 170-171.

${ }^{57} \mathrm{O}$ texto em inglês é: "The privilege of opening the first trial in history for crimes against the peace of the world imposes a grave responsibility. The wrongs which we seek to condemn and punish have been so calculated, so malignant, and so devastating, that civilization cannot tolerate their being ignored, because it cannot survive their being repeated.". Justice Jackson's Opening Statements for the Prosecution. University of Missouri-Kansas City School of Law. Apresenta registros do Tribunal de Nuremberg. Disponível em: <http://www.law.umkc.edu/faculty/projects/ftrials/nuremberg/jackson.html>. Acesso em: 14 set. 2010.
} 
como fim a condenação dessas injustiças, consideradas crimes contra a paz mundial. É grave também em razão da magnitude do julgamento. Assim, continuou Jackson: "Nunca antes na história jurídica foi feito um esforço para trazer, no âmbito de um processo único, os empreendimentos de uma década, cobrindo todo um continente (...) ${ }^{, 58}$. Dada a pretensão de se estabelecer como o Tribunal a julgar os empreendimentos de uma década, o mais importante, todavia, é que a responsabilidade é grave, pois, ao assumir o poder de decidir, os julgadores podem ser tão cruéis quanto os nazistas foram. O privilégio de abrir o julgamento pode ser entendido como o poder do ineditismo de julgar os nazistas, para poder depois finalmente começar a falar em paz, sendo assim uma colaboração para a sua restauração na ordem internacional. Para isso era preciso condenar o cálculo maligno e devastador.

Ocorre que o Tribunal de Nuremberg foi um cálculo a posteriori - primeiro sinal de devastação -, apresentando-se como "direito". Só que não se apresentou puramente como "direito", mas sim como "direito de matar" - segundo sinal de devastação -. A atividade de matar é muitas vezes consequência do que é maligno. Por certo não se admitiu a ignorância dos atos perpetrados pelos nazistas, contudo eles se repetiram, a partir do momento em que nós os matamos, quando eram meramente réus, e não mais combatentes. Assim repetimos. E ao repetir deixamos de sobreviver ao nazismo. Fomos condenados a conviver com esse rastro na história, sem ter tido força para buscar uma civilidade suficiente para dar uma resposta contrária ao nacional-socialismo. Ao matar, absolvemos o nazismo. As "sinistras influências" ${ }^{\text {,59 }}$ dos nazistas, outrora temidas pelo próprio Jackson, concretizaram-se.

O pensador Jacques Derrida chamou a atenção para o fundamento teológico-político da pena de morte, que é na verdade "uma aliança entre uma mensagem religiosa e a soberania de um Estado"60. Essa abertura às questões morais transcendentais se reflete inclusive nos tipos abertos imputados aos nazistas, que possuíam certo caráter transcendental, como o conceito de "guerra de agressão" ou o conteúdo do que seria um "ato desumano cometido contra populações civis", conforme disposto no artigo $6^{\circ}$, do Estatuto de Nuremberg ${ }^{61}$. A pena de morte pode ser historicamente lida como um rito sacrificial para que o criminoso expiasse os seus pecados, para assim ser salvo em um mundo transcendental (o além da vida). Essa não

\footnotetext{
${ }^{58}$ No idioma original: "Never before in legal history has an effort been made to bring within the scope of a single litigation the developments of a decade, covering a whole continent, and involving a score of nations, countless individuals, and innumerable events." Loc. Cit.

${ }^{59}$ Nuremberg Trials - Opening Statement of Robert Jackson. Transitional Justice - reconstructing self and society. Apresenta registros do Tribunal de Nuremberg. Disponível em: <http://tj.facinghistory.org/nurembergtrials-opening-statement-robert-jackson>. Acesso em: 14 set. 2010.

${ }^{60}$ DERRIDA, Jacques; ROUDINESCO, Elizabeth. De que amanhã: diálogo, p. 173.

${ }^{61}$ FERRO, Ana Luiza Almeida. O Tribunal de Nuremberg: dos precedentes à confirmação de seus princípios, $\mathrm{p}$. 95-98.
} 
é uma concepção de punição que pode ser aceita em uma ordem laica, pois condiciona a punição à aceitação de postulados religiosos, que são de ordem privada. Obliterando esse viés religioso, dependente de uma realidade transcendental, sobra a retribuição à pena de morte como justificação derradeira, cuja lógica kantiana se desenvolve ao ousar calcular o retorno a cada um do mal cometido. Quando, diante do cálculo, a pena de prisão extrapola o tempo de vida do réu, o que resta é a pena de morte, a ser aplicada às piores violações do direito, que é por si só o desmoronamento do cálculo, pois as maiores violações são temporalmente incalculáveis.

A leitura do filósofo francês coaduna a essência religiosa do castigo supremo com a sua natureza intrínseca de exceção. É interessante como Derrida, ao citar Carl Schmitt, liga o poder de vida e morte sobre os súditos com a questão da exceção. O próprio assassinato legal já seria por si só uma suspensão do direito, por meio da prerrogativa do "direito de suspender o direito" $"$. Por essa ótica, a pena de morte foi um elemento do julgamento que retirou a racionalidade laica do Tribunal de Nuremberg. A legalidade foi um problema menor, se comparado à ausência da humanidade dessa sanção. Em uma ordem laica a pena de morte não deveria ser legítima, em razão do seu fundamento teológico-político na salvação da alma pelo sacrifício. Ela não tem o objetivo de salvar materialmente a sociedade, mas de purificar a alma do culpado ${ }^{63}$. Não pretendo aqui afirmar que a pena de morte não seja possível de ser adaptada à lógica de um estado laico, mas sim que a laicidade abre uma série de opções racionais que dispensam a pena de morte, assim a mera retributividade ou a defesa do estado podem ser postos de lado, no que se referem à existência da pena de morte. Os Aliados fundamentariam com mais apurada razão a suspensão do Direito Internacional, para atribuir responsabilidades aos nazistas, se o processo e o resultado tivessem sido mais brandos do que a execução sumária. Ao matá-los, eles suspenderam uma melhor justificativa afetiva e racional para a exceção, que poderia ter nos deixado uma herança de lutas mais aprazível.

Após revelar o caráter teológico-político da pena de morte, Derrida elabora uma afirmação polêmica: “(...) ousaria dizer que a pena de morte sempre correspondeu a pleitos profundamente "humanistas", ${ }^{\prime}$. Ele quis dizer com essa assertiva que é a concepção da dignidade do ser humano como fim, que o autoriza a "arriscar a sua vida" no sacrifício, para atingir uma vida melhor (mais digna) após a morte. O sacrifício se dá em razão da dignidade do próprio homem. Em suas palavras: “(...) é a dignidade (Würde) incomparável da pessoa

\footnotetext{
${ }^{62}$ DERRIDA, Jacques; ROUDINESCO; Elizabeth. Op. Cit., p. 174.

${ }^{63}$ DERRIDA, Jacques; ROUDINESCO; Elizabeth. Op. Cit., p. 176.

${ }^{64}$ Ibid., p. 178.
} 
humana que, fim em si e não meio, segundo Kant, transcende sua condição de vivente e para a qual é uma honra inscrever a pena de morte em seu direito" ${ }^{~} 65$. Essa crítica que Derrida faz ao humanismo não é uma aposta naquilo que é inumano ou uma apologia à hostilidade ao homem. Pelo contrário, o que se leva a cabo é uma desconfiança à imperatividade da apropriação de um discurso dos valores do homem, o qual acaba se fechando em si mesmo e privilegiando o "nós" em detrimento do outro. O filósofo Paulo Cesar Duque-Estrada desconstrói a questão:

“(...) tal como o conceito de "signo", que existe para se apagar na sua referência ao significado, também o homem deve se apagar na sua referência àquilo que lhe confere dignidade enquanto ser-humano. Portanto, insistir no homem significa insistir na clausura de um certo "algo" - que é também e já um fim dele mesmo que reúne a todos em um "nós", "nós" homens, "nós" seres humanos. Isso traz uma série de complicações que, de imediato, não se percebe nas manifestações "em defesa" ou "em prol" do homem ou do "nós" homens; afinal, nunca se interroga ali de que "nós" se trata: que ou quem é esse "nós", quem afirma esse "nós", com base em quê, com vistas a quê, em que condições esse "nós" é afirmado, etc. ${ }^{66}$

A crítica ao humanismo é um movimento de descentralização do sujeito único e delineado de valores na ordem das coisas. Ela vem para permitir o acolhimento do absolutamente outro. Configurando-se em uma abertura à alteridade. Uma lei que agora se dirige ao imprevisível de quem não é nem presença nem ausência. Pela escrita de DuqueEstrada: "Lei da hospitalidade, que é também aquela da différance, do rastro, da pura afirmatividade de um sim à inesperada vinda do outro" ${ }^{\text {, }}$. É nesse sentido que reafirmo que os empreendedores do projeto genocida do século XX jamais deveriam ter sido eliminados, pois a resposta contra a destruição exige a permanência e o movimento de todos os outros, inclusive os julgados em Nuremberg, para permitir a potencialização da negação à supressão das vidas. A pena privativa de liberdade seria então uma boa alternativa ao resultado desse processo histórico, impedindo a eliminação dos outros, desconstituindo a figura do inimigo e respeitando as vítimas, já que responsabilizaria os nazistas, atribuindo consequências aos seus atos.

O anseio dos Aliados em fundamentar e justificar o "direito" apenas serviu para inserir, reinserir e reforçar o cálculo; a contabilidade acerca dos crimes praticados pelos nazistas em relação às penas que deveriam receber. A pena de morte também integra o cálculo da pena. Ela é um dos resultados da conta que busca a equivalência entre a gravidade do crime e a pena. Diz Derrida: “(...) A questão da pena de morte não é apenas a da onto-teologia

\footnotetext{
${ }^{65}$ Ibid., p. 178, grifos do autor.

${ }^{66}$ DUQUE-ESTRADA, Paulo Cesar. "Derrida e a crítica heideggeriana do humanismo". In: NASCIMENTO, Evando (Org.). Jacques Derrida - Pensar a desconstrução. São Paulo; Estação Liberdade, 2005, p. 254.

${ }^{67}$ DUQUE-ESTRADA, Paulo Cesar. "Derrida e a crítica heideggeriana do humanismo". In: NASCIMENTO, Evando (Org.). Jacques Derrida - Pensar a desconstruçã, p. 255.
} 
política da soberania; é também - em torno desse cálculo de uma impossível equivalência entre crime e castigo, de sua incomensurabilidade (...)." ${ }^{\text {68 }}$. Quando o crime praticado é considerado extremamente grave, a ponto de não encontrar equivalência em qualquer cominação de pena privativa de liberdade, então se aplica a pena de morte. A lógica kantiana se desmoronou diante dos crimes dos nazistas, pois a própria morte de seus artífices não foi suficiente como equivalência às destruições perpetradas. Assim, a "lógica" da pena de morte também esteve em xeque, quiçá desmoronou-se também.

Enfim, o problema do Tribunal de Nuremberg não foi a sua existência. Ele foi um processo histórico derradeiro. O triste no julgamento foi a ausência de crise dos princípios nazistas. A carência de desapego da vingança em seu cerne. As certezas, as oposições e as afirmações inflamadas não deram espaço para uma crise mais profunda; para um desmonte maior. Nos caminhos derridianos, "a desconstrução é a justiça"69.

\section{Conclusão}

Embora o perdão não esteja intrinsecamente relacionado ao direito e às instituições, podendo existir mesmo após as condenações mais rígidas, é inegável que o caráter extremamente aflitivo e eliminatório da pena de morte dificulta a sua manifestação. Rejeitar o castigo supremo seria estabelecer um ponto de virada em relação aos acontecimentos da Segunda Guerra Mundial. No entanto, não houve surpresas.

Caminhamos previsíveis e diretos em direção às respostas com mais morticínios, destruições e choques. Perdoar o imperdoável era uma tarefa impossível naquele momento, mas a busca do impossível leva tempo. Tempo esse retirado dos nazistas, dos aliados e do mundo. Os nós de virada foram desatados. Restaram muitas dúvidas eliminadas e as respostas dadas foram vermelhas. Será possível um dia perdoar toda essa história? Será possível ainda se ter estima pela humanidade? Questões demasiadamente imensas para serem respondidas neste escrito tão simples. Ouso, porém, sofrer para responder o questionamento por vir.

É possível haver justiça em tribunais de exceção? Sim e não. Sim, caso eles sejam menos violentos que a vingança coletiva, desconfigurando-se a justiça no processo de

\footnotetext{
${ }^{68}$ DERRIDA, Jacques; ROUDINESCO, Elizabeth. De que amanhã: diálogo, p. 183.

${ }^{69}$ DERRIDA, Jacques. Força de lei: o fundamento místico da autoridade. São Paulo: WMF Martins Fontes. $1^{\mathrm{a}}$ ed., 2007, p. 27, grifos do autor.
} 
desmonte, de quebra, de desconstrução; jamais na própria condenação ou absolvição irrefratáveis, no direito posto, no bater do martelo dos pragmatismos. Não, se rejeitarem um mínimo de abertura aos que estão sendo julgados, tornando-se eles mesmos uma vingança institucionalizada. Ultrapassar o princípio da legalidade não foi a maior falha do Tribunal de Nuremberg, pois em determinadas conjunturas históricas a ultrapassagem simplesmente se dará, independente do que estiver positivado. O pior disso tudo foi a impossibilidade de diferenciar substancialmente o "direito" que mata da guerra que mata. Por fim, o kairós do perdão esteve e ainda está ausente.

\section{REFERÊNCIAS:}

BATISTA, Nilo. Introdução Crítica ao Direito Penal Brasileiro. Rio de Janeiro: Revan, $11^{\text {a }}$ ed., 2007. 136.

BITENCOURT, Cezar Roberto. Tratado de Direito Penal - Parte Geral. São Paulo: Saraiva, $14^{\mathrm{a}}$ ed., 2009. $853 \mathrm{p}$.

BRUNO, Anibal. Direito Penal - Parte Geral. Rio de Janeiro: Forense, 3ª ed., 1967. 395 p.

DERRIDA, Jacques; ROUDINESCO; Elizabeth. De que amanhã: diálogo. Rio de Janeiro: Jorge Zahar Ed., 2004. 239 p.

DERRIDA, Jacques. Força de lei: o fundamento místico da autoridade. São Paulo: WMF Martins Fontes. $1^{\mathrm{a}}$ ed., 2007. 145 p.

DUQUE-ESTRADA, Paulo Cesar. "Derrida e a crítica heideggeriana do humanismo". In: NASCIMENTO, Evando (Org.). Jacques Derrida - Pensar a desconstrução. São Paulo; Estação Liberdade, 2005. 352 p.

DIAS, Jorge de Figueiredo. Liberdade, Culpa, Direito Penal. Coimbra: Coimbra Editora, $3^{\mathrm{a}}$ ed, 1995. $317 \mathrm{p}$.

FERRO, Ana Luiza Almeida. O Tribunal de Nuremberg: dos precedentes à confirmação de seus princípios. Belo Horizonte: Mandamentos, 2002. 165 p. 
GONÇALVES, Joanisval Brito. Tribunal de Nuremberg 1945-1946: a gênese de uma nova ordem no direito internacional. Rio de Janeiro: Renovar, 2001. 379 p.

GRECO, Rogério. Curso de Direito Penal - Parte Geral. Rio de Janeiro: Impetus, $12^{\mathrm{a}}$ ed, 2010. 753 p.

GUYAU, Jean-Marie. Crítica da idéia de sanção. São Paulo: Martins, 2007. 94 p.

HADDOCK-LOBO, Rafael. "As muitas faces do outro em Levinas". In: DUQUEESTRADA, Paulo Cesar (Org.). Desconstrução e ética - ecos de Jacques Derrida. Rio de Janeiro : Ed. Puc-Rio, 2004. 247 p.Penal, v. 1, t.1. Rio de Janeiro: Forense, 4ª Ed, 1958, 247 p.

JAPIASSÚ, Carlos Eduardo Adriano. O Direito Penal Internacional. Belo Horizonte: Del Rey, 2009. 134 p.

Justice Jackson's Opening Statements for the Prosecution. University of Missouri-Kansas City School of Law. Apresenta registros do Tribunal de Nuremberg. Disponível em: <http://www.law.umkc.edu/faculty/projects/ftrials/nuremberg/jackson.html>.

KELSEN, Hans. Will the judgment in Nuremberg Trial constitute a precedent in International Law? The International Law Quarterly, v. 1, n. 2, p. 153-171, 1947.

Nuremberg Trials - Opening Statement of Robert Jackson. Transitional Justice reconstructing self and society. Apresenta registros do Tribunal de Nuremberg. Disponível em: <http://tj.facinghistory.org/nuremberg-trials-opening-statement-robert-jackson>.

PRADO, Luiz Regis. Curso de direito penal brasileiro, parte geral: arts. $1^{\circ}$ a 120 . São Paulo: Revista dos Tribunais, $8^{\mathrm{a}}$ ed,.2008. $701 \mathrm{p}$.

ROXIN, Claus. Derecho Penal-Parte General, t. 1. Madrid: Civitas, 2ª ed., 2008. 1071 p.

SANTOS, Juarez Cirino dos. Direito Penal - Parte Geral. Florianópolis: Conceito Editorial, $4^{\mathrm{a}}$ ed., 2010. $697 \mathrm{p}$.

SCHMITT, Carl. Teología política - cuatro ensayos sobre la soberanía. Buenos Aires: Struhart \& Cia, 2005. 203 p.

SHKLAR, Judith N. Legalism - Law, Morals and Political Trials. London: Harvard University Press, 1986. 246 p. 
United States Holocaust Memorial Museum. Enciclopédia do Holocausto. Apresenta informações sobre o Holocausto. <http://www.ushmm.org/museum/exhibit/focus/portuguese/>. 